\title{
Antimutagenic and Anticarcinogenic Effect of Methanol Extracts of Sweetpotato (Ipomea batata) Leaves
}

\author{
Hwan-Goo Kang', Sang-Hee Jeong' and Joon-Hyoung Cho' \\ ${ }^{1}$ National Research and Quarantine Service, Anyang 430-757 \\ ${ }^{2}$ Hoseo University, Asan 336-851, Korea
}

(Received February 4, 2010; Revised February 22, 2010; Accepted February 25, 2010)

\begin{abstract}
The present study was conducted to investigate the antimutagenic potential of the methanolic extract from the leaves of sweet potato (Ipomea batatas, IB) with the SOS chromotest (umu test) and Salmonella typhimurium TA 98 and TA 100 . The anticarcinogenic effects were also studied by calculation of the $\mathrm{IC}_{50}$ on human cancer cell lines and investigating the function of gap junction in rat liver epithelial cells. The IB extract inhibited dose-dependently the $\beta$-galactosidase activity induced spontaneously at concentration of more than $200 \mathrm{mg} / \mathrm{m} l$ in $S$. typhimurium TA $1535 / \mathrm{pSK} 1002$, and decreased significantly $(p<0.01)$ the $\beta$ galactosidase activities induced by mutagen 6-chloro-9-[3-(2-chloroethylamino)proylamino]-2-methoxyacridine dihydrochloride (ICR) at dose of more than $0.4 \mathrm{mg} / 0.1 \mathrm{ml}$. The IB extract showed no effect on the spontaneous reversions of $S$. typhimurium TA 98 and 100 but benzo( $\alpha$ )pyrene $(\mathrm{BaP})$-stimulated reversions were decreased dose-dependently $(p<0.01)$ at the concentration of more than $100 \mathrm{mg} / \mathrm{ml}$. The $\mathrm{IC}_{50}$ value of stomach cancer cells was lower than that of normal rat liver epithelial cells, but the values of colon and uterine cancer cell lines were similar to those of normal rat liver epithelial cells. The transfer of dye through gap junctions was not affected by treatment of the IB extracts at any concentration during treatment periods. The simultaneously treatment of IB extract and 12-O-tetradecanoylphorbol-13-acetate (TPA) effectively prevented the inhibition of dye transfer induced by TPA 1 hour after treatment at all exposed concentrations. The number of gap junctions was significantly $(p<0.01)$ increased by the treatment with IB extract at concentrations of more than $40 \mu \mathrm{g} / \mathrm{m} l$. The inhibition of the expression of gap junction proteins by TPA $(0.01 \mu \mathrm{g} / \mathrm{m} l)$ was recovered dose dependently by the simultaneous treatment of IB extracts. Our data suggest that Ipomea batatas has antimutagenic and anticarcionogenic activity in vitro.
\end{abstract}

Key words: Ipomea batatas, Antimutagenicity, Anticarcimogenicity, SOS chromotest (umu test), Salmonella typhmurium TA 98/100, Gap junction

\section{INTRODUCTION}

Many studies have been conducted to find components having anti-mutagenic and anti-carcinogenic activities from vegetables, fruits, and plants for the development of functional foods or drugs to prevent cancers. Some antimutagenic substances that have been identified from vegetables and fruits are vitamin $\mathrm{C}$, vitamin A, cysteine polyphenols and lignin-like compounds (Brockman et al., 1992; Edenharder et al., 1995; Hirono et al., 1975; Shinohara et al., 1988).

Sweet potato has been used as a primary food source for

Correspondence to: Sang-Hee Jeong, GLP Research Center, College of Natural Sciences, Hoseo University, Baebang 165, Asan 336-851, Korea

E-mail: Jeongsh@hoseo.edu human and its roots or leaves are used for beverages, powders, cakes, natural food colorants, traditional therapies, and alcoholic drinks (Islam, 2006; Suda et al., 2003; Sikdar, 2008). Ipomea batatas (IB) leaves are reported to have antioxidant compounds like polyphenols (Thompson, 1981). Purple-fleshed sweet potato cultivars have a relatively high free radical scavenging or antioxidant activity compared to those of white, yellow or orange flesh (Oki et al., 2002). Lyophilized leaf powder from sweet potato strongly suppressed the growth of food poisoning bacterial such as Staphylococcus aureus, Bacillus cereus, E coli ${ }^{0157}$ (Islam, 2006; Yoshimoto, 2001).

Anthocyanins, a kind of polyphenols, comprise the red, purple and blue pigmentation of many plants, including sweet potatoes. Anthocyanins may have potential physiological effect as antineoplastic (Kamei et al., 1995), radiation protective (Minkova et al., 1990), anti-inflammatory 
(Rabah et al., 2004), and hepatoprotective (Han et al., 2006) agents. Anthocyanin protected against the mutagenesis partly by direct reaction with enzymatically activated carcinogens (heterocyclic amines) rather than by interaction with metabolic enzymes (Yoshimoto et al., 1999). The antioxidant and anticarcinogenic effects of anthocyanine compound might depend on the number of hydroxyl group in the structure (Yoshimoto et al., 2001).

The Ames test was developed to screen mutagenicity of chemicals which can induce frame shift or base pair substitution of DNA (Maron and Ames, 1983). SOS chromotest (umu test) is a simple colorimetric assay to detect DNA damage by observing the expression of the SOS gene $(u m u C)$ fused with a lacZ gene ( $\beta$-galcosidase) and it has been used as an alternative method to detect mutagenicity of compounds (Oda et al., 1985).

Gap junctions are essential components for cell growth, proliferation and physiological function in communication between normal cells (Loewenstein, 1975). Gap junctions are generally down regulated in most cancer cells, so the studies on the effects of test compounds on the function of gap junctions have been used in prescreening assays for carcinogenicity (Klauing and Ruch, 1990). Therfore, the evaluation of test compound for the gap junction could be used as screen tool of carcinogenicity or anticarcinogenicity effects of chemicals. In authors' knowledge, few studies have been conducted to investigate the effect of IB to gap junctional intercellular communication (GJIC).

The objective of the present study is to identify the (anti-) mutagenic activities of the methanolic extract from leaves of IB through umu test and S. typhimurium TA 98, TA 100. The anticarcinogenic activity of the extract was also studied by calculating the inhibition ratio on cancer cell lines and evaluating the effect on the function of gap junctional intercellular communication assay in rat liver epithelial cells.

\section{MATERIALS AND METHODS}

Cells, bacterial strains and chemicals. The test strains of S. typhimurium TA 98 and TA 100 were kindly supplied by Dr. Bruce Ames in University of California (USA) and $S$ typhimurium TA 1535/pSK 1002 was provided by Dr. Oda in Perfectual Institute of Public Health (Japan). Stomach cancer cell (SNU-1), colon cancer cell (SNU-C-1), uterus cancer cell (ATCC-CCL-2), liver cancer cell (ATCC-HB8065), lung cancer cell(ATCC-CCL-185) were provide by Natural Product Research Institute of Seoul National University in Republic of Korea. Rat liver epithelial cell (WBF344) was kindly provided by Dr. JE Trosoko in Michigan State Universiy of USA. 6-chloro-9-[3-(2-chloroethylamino) proylamino]-2-methoxyacridine dihydrochloride (ICR), 12$O$-tetradecanoylphorobol-13-acetate (TPA), benzo $(\alpha)$ pyrene (BaP), dimethylsulfoxide (DMSO) were obtained from Sigma-Aldrich (St. Louis, MO, USA).
Preparation of methanol extracts of IB. The leaves of IB were collected in spring in Korea. They were washed with distilled water and ground using mortar. Resulting material was diluted with methanol $(1: 10)$ and extracted for 48 hour, then sonicated for 30 minute. Extracted solution were filtered through filter paper (Advantec $\phi 185 \mathrm{~mm}$ ) and dried under vacuum at $40^{\circ} \mathrm{C}$.

Sample preparation. Methanolic extracts of IB were dissolved in $50 \%$ DMSO at concentrations of $0.08,0.4,2$, 10 , and $50 \mathrm{mg} / \mathrm{m} l$ for (anti-)mutagenic assay and 8, 40, 200, 1,000 and $5,000 \mu \mathrm{g} / \mathrm{m} l$ for (anti-)carcinogenicity assay, respectively.

Umu test for (anti-)mutagenecity. Umu test was carried out according to the procedure developed by Dr. Oda et al. (1985). Briefly, S. typhimurium TA 1535/pSK 1002 was cultured at $37^{\circ} \mathrm{C}$ overnight in Luria broth medium including antibiotics, and then diluted 50-fold with TGA medium ( $1 \%$ bacto tryptone, $0.5 \% \mathrm{NaCl}, 0.2 \%$ glucose, $20 \mu \mathrm{g} / \mathrm{m} l$ ampicillin). It was further incubated at $37^{\circ} \mathrm{C}$ until the bacterial density reached $0.25 \sim 0.3$ of absorbance at $600 \mathrm{~nm}$. The bacterial cultures were subdivided into $2.4 l$ portions in test tubes, and $100 \mu l$ of test sample, $100 \mu l$ of positive control (ICR), and $0.5 \mathrm{~m} l$ of $\mathrm{S}_{9}$ mixture or PBS was added. The mixtures were incubated at $37^{\circ} \mathrm{C}$ for 2 hour. The expression of $u m u$ gene was calculated by determination of $\beta$-galactocidase activity according to Miller (1972).

(Anti-) mutagenicity assay in S. typhimurium TA 98 and TA 100. The pre-incubation method of Marson and Ames (1983) was applied to study the (anti-) mutagenic effect of IB extract. Briefly, $0.1 \mathrm{~m} l$ from an overnight culture of $S$. typhimurium TA 98 or TA 100 were added to $0.1 \mathrm{~m} l$ of each test sample, $0.1 \mathrm{~m} l$ of positive control (BaP) or vehicle, and $0.5 \mathrm{~m} l$ of $\mathrm{S}_{9}$ mixture or PBS. The entire mixture was incubated at $37^{\circ} \mathrm{C}$ in a rotary shaker $(125 \mathrm{rpm})$ for 20 minute. After incubation, $2.0 \mathrm{~m} l$ of $0.5 \mathrm{M}$ his/bio top agar was added, and then poured onto minimum glucose agar and further incubate for 48 hour. Toxicity of test samples was determined by examination of background lawn. $\mathrm{S}_{9}$ mixture was prepared by the method of Maron and Ames (1983) and $1 \mathrm{ml}$ of mixture was mixed with $9 \mathrm{ml}$ of cofactors.

Assay for $50 \%$ inhibition concentrations of IB extract for cancer cell growth. The determination of the $50 \%$ inhibition concentration of the extract for each cancer cell line was carried out by MTT (3-[4,5-dimethythiazol-2-yl]2,5-diphenyl-tetrazolium bromide) assay. After the treatment of extract to cancer cells and normal rat liver epithelial cells in 96 well plate for 4 days, cells were washed twice with $37^{\circ} \mathrm{C}$ PBS and then added $0.1 \mathrm{~m} l$ of serum-free medium containing $0.1 \%$ MTT to each well. After incuba- 
tion for 4 hour, cells were centrifuged at $450 \times \mathrm{g}$ for 5 minute and the culture medium was removed. $0.1 \mathrm{~m} l$ of DMSO was added to each well to solubilize the formazan formed. The plates were shaken gently for 10 minute and the absorbance was measured at $570 \mathrm{~nm}$. The absorbance of treated cells was compared with that of controls, which cells were exposed only to the vehicle and were considered as $100 \%$ viability value. The determination of $50 \%$ inhibition concentration of IB extract for each cancer cell and rat liver epithelial cells was carried out by sigmoidal fitting method (Origin 6.0).

Scrape-loading and dye transfer (SLDT) assay. Gap junction intercellular communication (GJIC) was determined through the SLDT technique according to the method described by El-Fouly (1987). WB-F344 cells grown in 35$\mathrm{mm}$ tissue culture dish were exposed to the test compound with TPA for 1, 4, 8, 24 hour. After washing with $\mathrm{Ca}^{2+}$, $\mathrm{Mg}^{2+}$ - phosphate buffered saline (PBS) three times, $2 \mathrm{~m} l$ of $0.05 \%$ Lucifer yellow CH solution in PBS was added, and then several scrapes were made on the monolayer using a surgical blade. The cells were incubated for $3 \mathrm{~min}$ at room temperature and then washed 3 times with $\mathrm{Ca}^{2+}, \mathrm{Mg}^{2+}-\mathrm{PBS}$. The cells were fixed with $1 \mathrm{ml}$ of $10 \%$ buffered formalin solution. Dye transferred cells were observed with an inverted epifluorescence microscope ( $\times 100$, Nikon, Japan).

Immunofluorescent staining for gap junction proteins. Immunofluorescent staining for gap junction protein was carried out according to the method of Matesic (1994). After treatment of the test sample with or without $0.01 \mu \mathrm{g} /$ $\mathrm{m} l$ of TPA for 8 hour, the WB-F344 cells were fixed with cold methanol/acetone $(95: 5)$ for 30 minute, and then rehydrated with PBS. Nonspecific binding sites were blocked with $1 \%$ normal rabbit serum (Jackson, USA) in PBS for 30 minute at room temperature. The cells were incubated for 2 hour with mouse monoclonal anti-connexin 43 (Zymed, USA) diluted $1: 100$ in PBS, and then washed with PBS. The cells were treated with fluorescence isothiocyanateconjugated rabbit anti-mouse IgG (Jackson, USA) diluted $1: 100$ in PBS for 1 hour. Stained gap junction per cell were counted $(\times 1,000)$ using fluorescence microscope (Nikon, Japan).

Statistics. Statistical analyses of the data were performed using one-way ANOVA and Duncan's multicomparison test using PC-STAT version 1A.

\section{RESULTS}

Effect of the extract on $\beta$-galactosidase activity in S. typhimurium TA 1535/pSK 1002. Methanolic extracts of IB inhibited dose-dependently the $\beta$-galactosidase activity induced spontaneously at concentrations of more than $20 \mathrm{mg} /$
Table 1. Inhibitory effect of IB extract on the expression of SOS gene (umu C'-'lac Z fusion gene) induced spontaneously and by ICR in S. typhimurium TA1535/pSK1002

\begin{tabular}{cccc}
\hline \hline Treatment & $\begin{array}{c}\text { Dose } \\
(\mathrm{mg} / \mathrm{m} l)\end{array}$ & $\begin{array}{c}\text { Activity of } \text {-galactosidase }^{\mathrm{a}} \\
\text { Control }\end{array}$ & $\begin{array}{c}\text { Inhibition }^{\mathrm{b}} \\
\text { ratio }\end{array}$ \\
\hline IB & 0.8 & $118.4 \pm 1.3$ & 1.00 \\
& 4 & $113.8 \pm 1.3$ & 0.96 \\
& 20 & $113.6 \pm 0.8$ & 0.96 \\
& 100 & $93.9 \pm 2.1^{* *}$ & 0.90 \\
& 500 & $92.5 \pm 2.3^{* *}$ & 0.79 \\
\hline ICR & 0.3 & $* * 346.3 \pm 5.0$ & 1.00 \\
ICR & $0.3+0.8$ & $334.5 \pm 8.9$ & 0.97 \\
+ & $0.3+4$ & $322.0 \pm 2.7^{* *}$ & 0.91 \\
IB & $0.3+20$ & $258.6 \pm 2.9^{* *}$ & 0.67 \\
& $0.3+100$ & $178.1 \pm 2.6^{* *}$ & 0.37 \\
& $0.3+500$ & $122.5 \pm 1.6^{* *}$ & 0.13 \\
\hline
\end{tabular}

IB: Ipomea batatas.

ICR: 2-methoxy-6-chloro-9-(3-(2-chlorethyl)aminopropylamino)acridine . $2 \mathrm{HCl}$.

a: Activities of $\beta$-galactosidase were presented in unit and the values are mean \pm SE of 6 replica from which basal levels were not subtracted.

$\mathrm{b}$ : The ratios are defined as the value of the $\beta$-galactosidase unit of $I B$ divided by that of control in the case of $I B$ and as $\left(M_{1}-M_{2}\right) / M_{3}$ where $M_{1}$ is that of ICR +IB, $M_{2}$ is that of IB alone and $M_{3}$ is that of ICR alone from which that of control was subtracted in the case of $\mathrm{ICR}+\mathrm{IB}$.

* or **: Significantly different from control (in the case of IB and ICR) or ICR (in the case of ICR $+\mathrm{IB}$ ) at $p<0.05$ and $p<0.01$, respectively.

$\mathrm{m} l$ in $S$. typhimurium TA $1535 / \mathrm{pSK} 1002$. The $\beta$-galactosidase activities induced by mutagen ICR $(0.3 \mathrm{mg} / \mathrm{m} l)$ were also decreased significantly $(p<0.01)$ by IB extract at doses of higher than $4 \mathrm{mg} / \mathrm{m} l$ (Table 1).

Effect on the revertants in S. typhimurium TA 98 and TA 100. All doses of IB extract (0.08 50 mg/plate) showed no effect on spontaneous reversion of $S$. typhimurium TA 98 and 100. All concentrations of the extract treated simultaneously with mutagen $\mathrm{BaP}(2 \mathrm{mg} /$ plate $)$ did not significantly change the increased revertants by $\mathrm{BaP}$ in $S$. typhimurium TA 100 , but in $S$. typhimurium TA $98, \mathrm{BaP}$ stimulated reversion was decreased dose-dependently $(p<0.01)$ at the concentration of higher than $100 \mathrm{mg} / \mathrm{ml}$ (Table 2).

Inhibition of the proliferation of cancer line cell. The mean $50 \%$ inhibition concentration $\left(\mathrm{IC}_{50}\right)$ of $\mathrm{IB}$ extract for cell proliferation was $244 \mu \mathrm{g} / \mathrm{m} l$ (with a $95 \%$ confidence interval (CI) of $19 \sim 309 \mu \mathrm{g} / \mathrm{ml}$ ) for human stomach cancer cells, which was lower than that for normal rat liver epithelial cells $1,035 \mu \mathrm{g} / \mathrm{m} l$ (CI of 105 10,224). The mean $50 \%$ inhibition concentrations for colon cancer cells and uterine cancer cells were 854 (CI of 715 1,019) and 950 (CI of $854-1,056)$, respectively. Their values were similar to that 
Table 2. Inhibitory effect of IB extract on the reversion frequency induced spontaneously and by BaP in S. typhimurium TA98 and TA100

\begin{tabular}{|c|c|c|c|c|c|}
\hline \multirow{2}{*}{ Treatment } & \multirow{2}{*}{$\operatorname{Dose}^{a}$} & \multicolumn{2}{|c|}{ TA98 } & \multicolumn{2}{|c|}{ TA100 } \\
\hline & & Revertant $^{\mathrm{b}}$ & Ratio $^{c}$ & Revertant $^{\mathrm{b}}$ & Ratio $^{c}$ \\
\hline \multirow[t]{5}{*}{ IB } & 0.08 & $51.4 \pm 4.0$ & 1.09 & $147.6 \pm 5.20$ & 0.97 \\
\hline & 0.4 & $46.1 \pm 2.1$ & 0.98 & $144.6 \pm 7.4$ & 0.95 \\
\hline & 2 & $50.6 \pm 3.1$ & 1.07 & $143.1 \pm 7.5$ & 0.94 \\
\hline & 10 & $46.6 \pm 2.0$ & 0.99 & $159.3 \pm 5.4$ & 1.05 \\
\hline & 50 & $40.8 \pm 2.8$ & 0.86 & BK & - \\
\hline $\mathrm{BaP}$ & 2 & $* * 314.6 \pm 15.3$ & 1.00 & $* * 604.4 \pm 46.7$ & 1.00 \\
\hline $\mathrm{BaP}$ & $2+0.08$ & $313.8 \pm 16.2$ & 0.98 & $604.8 \pm 51.6$ & 1.01 \\
\hline+ & $2+0.4$ & $337.8 \pm 9.2$ & 1.09 & $558.8 \pm 56.6$ & 0.92 \\
\hline \multirow[t]{3}{*}{ IB } & $2+2$ & $341.2 \pm 8.7$ & 1.09 & $599.6 \pm 44.7$ & 1.01 \\
\hline & $2+10$ & $231.8 \pm 16.9^{* *}$ & 0.69 & $665.5 \pm 43.8$ & 1.12 \\
\hline & $2+50$ & $51.1 \pm 3.1^{* *}$ & 0.04 & $\mathrm{BK}$ & - \\
\hline
\end{tabular}

\section{BaP: Benzo(a)pyrene.}

a: Units of doses of IB and BaP are $\mathrm{mg} /$ plate and $\mu \mathrm{g} /$ plate, respectively.

b: Revertants are the number of revertants/plate and the values of mean \pm SE of 9 replica from which the number of spontaneous revertants were not subtracted.

c: The ratios are defined as the number of the revertant of IB divided by that of control in the case of IB alone and as $\left(M_{1}-M_{2}\right) / M_{3}$ where $M_{1}$ is the number of revertants of $B a P+I B, M_{2}$ is that of IB alone and $M_{3}$ is that of $B a P$ alone from which the that of control was subtracted in the case of $\mathrm{BaP}+\mathrm{IB}$.

BK: Bacterial killing effect.

**: Significantly different from control (in the case of $\mathrm{BaP}$ ) or $\mathrm{BaP}$ (in the case of $\mathrm{BaP}+\mathrm{IB}$ ) at $p<0.01$.

Table 3. Inhibitory effects of IB extract on the growth of normal rat liver epithelial cells and human cancer line cells

\begin{tabular}{lc}
\hline \hline Cell type & $\mathrm{IC}_{50}(\mathrm{CI}) \mu \mathrm{g} / \mathrm{m} l$ \\
\hline Rat liver epithelial cell (WB-F344) & $1,035(105 \sim 10,224)$ \\
Stomach cancer cell (SNU-1) & $244(193 \sim 309)$ \\
Colon cancer cell (SNU-C-1) & $854(715 \sim 1,019)$ \\
Uterus cancer cell (ATCC-CCL-2) & $950(854 \sim 1,056)$ \\
Liver cancer cell (ATCC-HB-8065) & $2,125(1,331 \sim 3,393)$ \\
Lung cancer cell (ATCC-CCL-185) & $2,494(199 \sim 31,329)$ \\
\hline
\end{tabular}

$\mathrm{IC}_{50}$ is the concentration that shows $50 \%$ growth inhibition of cells in MTT assay.

Cl: $95 \%$ confidence interval.

of normal liver epithelial cell. In case of liver and lung cancer cells, $\mathrm{IC}_{50} \mathrm{~s}$ were 2,125 and $2,495 \mu \mathrm{g} / \mathrm{ml}$, respectively, which was about twice as high as that of normal rat liver epithelial cells (Table 3).

Effect of IB extract on gap junctional intercellular communication. Gap junctional intercellular communication was assessed by dye transfer through gap junctions after treatment of cells with IB extract. The transfer of dye through gap junctions was not affected by the treatment of the extracts at all concentrations during treatment periods. The simultaneously treatment of IB extract with TPA $(0.01$ $\mu \mathrm{g} / \mathrm{m} l)$ effectively prevented the inhibition of dye transfer induced by TPA 1 hour after treatment at all exposure concentrations (Table 4).
Effect of IB extract on the expression of gap junction protein. The number of gap junctions was significantly $(p<0.01)$ increased by treatment with IB extract at concentrations of more than $40 \mu \mathrm{g} / \mathrm{m} l$. The inhibition of gap junction expression by TPA $(0.01 \mu \mathrm{g} / \mathrm{m} l)$ was recovered dose dependently by the simultaneous treatment with IB extract (Table 5).

\section{DISCUSSION}

These studies show that methanol extract of IB itself was not mutagenic in either S. typhimurium TA $1535 / \mathrm{pSK}$ or $S$. typhimurium TA 98 and 100. On the other hand, it showed antimutagenic activity by inhibiting the $\beta$-galactosidase activity induced spontaneously and by mutagen ICR in S. typhimurium TA 1535/pSK1002. Antimutagens are classified desmutagens which can inactivate mutagens by directly binding mutagens before gene damage occurs, and bioantimutagens which can affect the recovery or replication of damaged genes (Kuroda and Hara, 1999). Antimutagens exhibit their activities either by correction of the error-prone SOS response or enhancement of an error-free recombinational repair system (Kakinuma et al., 1986).

Although IB extract did not influence the reversion induced spontaneously and by a mutagen in S. typhimurium TA 100 , it decreased the reversion produced by mutagen $\mathrm{BaP}$ without showing any effect on the spontaneous reversion of $S$. typhimurium TA 98. S. typhimurium TA 98 can detect the reversion caused by frame shift mutation, and S. typhimu- 
Table 4. Effect of IB extract on the gap junctional permeability in WB-F344 rat liver epithelial cells treated with/without TPA

\begin{tabular}{cccccc}
\hline \hline \multirow{2}{*}{ Treatment } & \multirow{2}{*}{$\begin{array}{c}\text { Dose } \\
(\mu \mathrm{g} / \mathrm{m} l)\end{array}$} & 1 & 4 & \multicolumn{3}{c}{ No. of dye-transferred cell } \\
\cline { 3 - 5 } & - & $183.2 \pm 5.6$ & $189.9 \pm 3.5$ & $200.8 \pm 7.2$ & $24 \mathrm{hrs}$ \\
\hline Control & 8 & $187.3 \pm 6.1$ & $188.7 \pm 4.9$ & $208.5 \pm 6.8$ & $213.2 \pm 7.9$ \\
IB & 40 & $179.0 \pm 1.9$ & $203.0 \pm 8.4$ & $206.5 \pm 3.4$ & $217.8 \pm 4.1$ \\
& 200 & $190.0 \pm 11.0$ & $203.7 \pm 3.2$ & $183.5 \pm 7.9$ & $208.0 \pm 6.1$ \\
& 1,000 & $189.8 \pm 6.8$ & $190.5 \pm 6.2$ & $193.3 \pm 5.0$ & $218.0 \pm 1.7$ \\
& 5,000 & $177.7 \pm 5.0$ & $223.8 \pm 6.3^{* *}$ & $208.3 \pm 8.9$ & $205.0 \pm 6.2$ \\
\hline TPA & 0.01 & $* * 14.8 \pm 1.6$ & $* * 16.5 \pm 1.3$ & $* * 21.2 \pm 2.2$ & $* * 72.0 \pm 4.5$ \\
TPA & $0.01+8$ & $16.2 \pm 1.0$ & $60.5 \pm 5.5^{* *}$ & $70.2 \pm 7.7^{* *}$ & $133.3 \pm 6.3^{* *}$ \\
+ & $0.01+40$ & $20.5 \pm 2.8^{*}$ & $90.0 \pm 4.0^{* *}$ & $93.7 \pm 10.4^{* *}$ & $166.0 \pm 4.5^{* *}$ \\
IB & $0.01+200$ & $31.0 \pm 1.9^{* *}$ & $95.3 \pm 5.2^{* *}$ & $97.6 \pm 5.5^{* *}$ & $189.5 \pm 5.3^{* *}$ \\
& $0.01+1,000$ & $27.2 \pm 0.7^{* *}$ & $100.5 \pm 6.7^{* *}$ & $107.2 \pm 8.3^{* *}$ & $168.0 \pm 3.2^{* *}$ \\
& $0.01+5,000$ & $29.7 \pm 1.0^{* *}$ & $110.8 \pm 6.5^{* *}$ & $92.7 \pm 5.2^{* *}$ & $178.2 \pm 4.2^{* *}$ \\
\hline
\end{tabular}

TPA: 12-O-tetradecanoylphorbol-13-acetate.

a: The values presented are the mean \pm SE of 12 (1 hour) or 9 (4, 8 and 24 hour) replica.

${ }^{*}$ or ** : Significantly different from control (in the case of IB and TPA) or TPA (in the case of TPA + IB) at $p<0.05$ and $p<0.01$, respectively.

Dye-transferred cells are examined under epifluorescence microscope ( $\times 200$ magnification).

Table 5. Effect of IB extract on the expression of gap junction protein in WB-F344 rat liver epithelial cells at 8 hour after the treatment with/without TPA

\begin{tabular}{|c|c|c|c|}
\hline Treatment & $\begin{array}{c}\text { Dose } \\
(\mu \mathrm{g} / \mathrm{m} l)\end{array}$ & 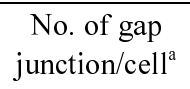 & $\begin{array}{c}\text { Induction } \\
\text { ratio }^{\text {b }}\end{array}$ \\
\hline Control & - & $10.8 \pm 0.6$ & 1.00 \\
\hline \multirow[t]{5}{*}{ IB } & 8 & $11.4 \pm 0.4$ & 1.06 \\
\hline & 40 & $12.8 \pm 1.0^{* *}$ & 1.19 \\
\hline & 200 & $14.6 \pm 0.5^{* *}$ & 1.35 \\
\hline & 1,000 & $15.4 \pm 0.5^{* *}$ & 1.43 \\
\hline & 5,000 & $16.2 \pm 0.3^{* *}$ & 1.50 \\
\hline TPA & 0.01 & $* * 4.1 \pm 0.2$ & 0.38 \\
\hline TPA & $0.01+8$ & $5.3 \pm 0.1$ & 0.49 \\
\hline+ & $0.01+40$ & $6.8 \pm 0.1^{*}$ & 0.63 \\
\hline \multirow[t]{3}{*}{ IB } & $0.01+200$ & $7.3 \pm 0.6^{* *}$ & 0.68 \\
\hline & $0.01+1,000$ & $9.6 \pm 0.7 * *$ & 0.89 \\
\hline & $0.01+5,000$ & $11.0 \pm 0.8^{* *}$ & 1.02 \\
\hline
\end{tabular}

a: The values presented are the mean \pm SE of 6 replica.

$\mathrm{b}$ : The ratio is defined as the number of the gap junction proteins expressed per cell of IB, TPA and TPA + PJ divided by that of control.

${ }^{*}$ or **: Significantly different from control (in the case of IB and TPA) or TPA (in the case of TPA + IB) at $p<0.05$ or $p<0.01$, respectively.

rium TA 100 can detect the reversion originated by basepair substitution (Maron and Ames, 1983). Caffeoylquinic acid derivatives isolated from sweet potato leaves effectively inhibited the reverse mutation induced by Trp-p-1 in S. typhimurium TA 98 (Shahidul Islam et al., 2003; Islam, 2006). These data suggest that IB extract could inhibit the mutagenesis produced by frame shift because it inhibits only the mutagenic activity in S. typhimurium TA 98 but not in S. typhimurium TA 100.
The different results between above two test methods could be based on the principle of each test; the umu test detect SOS repair mechanisms using $\beta$-glactosidase activity, whereas the $S$. typhimurium Ames' tests count the finial revertant involved in various type of gene mutations such as base-pair mutation and frame shift mutation (Oda et al., 1985, 1993; Kakinuma et al., 1986; Ishibashi et al., 1987). From our data, IB might have bioantimutagenic activity because the extract inhibited dose-dependently the gene damage induced spontaneously in S. typhimurium TA 1535/ pSK1002. We also suggest that the methanolic extract of IB might have desmutagenic activity in that it inhibited the gene mutation or SOS response induced by positive mutagen in both $S$. typhimurium TA $1535 / \mathrm{pSK} 1002$ and S. typhimurium TA 98.

Sweet potato leaves contain a high content of polyphenolics that consist of caffeic acid, chlorogenic acid, 3,4-di- $O$ caffeoylquinic acid, 3,5-di-O-caffeoylquinic acid, 4,5-di- $O$ caffeoylquinic acid, and 3,4,5-tri- $O$-caffeoylquinic acid (Truong et al., 2007). Caffeic acid and di- and tricaffeoylquinic acids depress dose-dependently human cancer cell proliferation such as stomach cancer cells, colon cancer cells, and promyelocytic leukemia cells (Kurata et al., 2007). Present result showed that the $\mathrm{IC}_{50}$ for gastric cancer cells was lower than that of normal liver epithelial cells, whereas it was similar for uterine cancer cells and colon cancer cells comparing that for normal rat liver epithelial cells. These data suggest that natural products can show different effects according to the type of cancer cells, there appears to be a specific relationship between the natural product and cancer inhibition. And also, IB may have preventive effects on the proliferation of gastric cancer cells.

In the present study, the methanol extract of IB increased 
the transfer of dye and also obstructed the inhibition of dye transfer by TPA in normal rat liver epithelial cells. The extract alone also increased the number of gap junctions and recovered the decreased gap junction by TPA. The inhibition of GJIC in cells is suggested to be related to carcinogenesis of nongenotoxic chemicals and developmental toxicities (Resenkranz et al., 2000). Cancer cells are devoid of gap junctions so that contact inhibition of cell proliferation does not occur and growth control is not properly operated, unlike in normal cells containing gap junctions (Enomoto and Yamasaki, 1984; Fitzgerald et al., 1993).

IB has plentiful polyphenol compound like anthocyanine, which have a lot of antimutagenic hydroxyl groups (Yoshimoto et al., 1999; Islam, 2006; Islam et al., 2006) and the biological activity is associated with number of sugar units and hydroxyl group on the aglycone (Yoshimoto et al., 2001). These reviews support the hypothesis that distinctive polyphenolic components with high contents of mono-, di-, and tricaffeoylquinic acid derivatives in methanol extract could be a source of anticarciongenic and antimutagenic effects.

Even though IB extract increases GJIC function in normal rat hepatocytes, there is some question as to whether it also shows anticarcinogenic activity in human liver cancer cells. In the present study, IB extract show presented no difference in $\mathrm{IC}_{50}$ values between human liver cancer cells and normal rat liver cells. Further studies are required to validate the anticacinogenic activity of leaves of IB with regard to GJIC function in cancer cells.

\section{ACKNOWLEDGEMENTS}

This work was supported by the fund from National Veterinary Research and Quarantine Service in Korea.

\section{REFERENCES}

Brockman, H.E., Stack, H.F. and Waters, M.D. (1992). Antimutagenicity profiles of some natural substance. Mut. Res., 267, 157-172.

Edenharder, R., Leopold, C. and Kries, M. (1995). Modifying actions of solvent extracts from fruit and vegetable residues on 2-amino-3-methylimidazo[4,5-f]quinoline (IQ) and 2-amino-3,4dimethylimidazo[4,5-f]quinoxaline (MeIQx) induced mutagenesis in Salmonella typhimurium TA 98. Mut. Res., 341, 303-318.

El-Fouly, M.H., Trosko, J.E. and Chang, C.C. (1987). Scrape-loading and dye transfer: A rapid and simple technique to study gap junctional intercellular communication. Exp. Cell Res., 168, 422-430.

Enomoto, T. and Yamasaki, H. (1984). Lack of intercellular communication between chemically transformed and surrounding non-transformed BALB/C 3 T3 cells. Cancer Res., 44, 52005203.

Fitzgerald, D.J, Swierenga, S.H.H., Mesnil, M., Piccoli, C., Marceau, N. and Yamaski, H. (1993). Gap junctional intercellular communication and connexin expression expression in nor- mal and SV40-transformed human liver cell in vitro. Cancer Let., 71, 157-165.

Han, K.H., Hashimoto, N., Shimada, K.I., Sekikawa, M., Noda, T., Yamauchi, H., Hashimoto, M., Chiji, H., Topping, D.L. and Fukushima, M. (2006). Hepatoprotective effect of purple potatoes extract against $\mathrm{D}$-galactosamine induced liver injury in rat. Bios. Biotech. Biochem., 70, 1432-1437.

Hirono, I., Sasaoka, I., Shibuta, C., Shimizu, M., Fushimi, K., Mori, H., Kato, K. and Haga, M. (1975). Natural carcinogenic products of plant origin. GANN, 17, 205-215.

Ishibashi, K., Takahashi, W., Takei, H. and Kakinuma, K. (1987). Possible interaction of thiol groups of protein with antimutagen containing a conjugated carbonyl structure. Agric. Biol. Chem., 51, 1045-1049.

Islam, S. (2006). Sweet potatos (Ipomea batatas L.) leaf: its potential effect on human health and nutrition. J. Food Sci., 71, R13R21.

Islam, S., Yoshimoto, M. and Yamakawa, O. (2006). Distribution and physiological function of caffeolyquinic acid derivatives in leaves of sweet potato genotypes. J. Food Sci., 68, 111-116.

Kamei, H., Kojima, T., Hasegawa, M., Koide, T., Umeda, T., Yukawa, T. and Terabe K. (1995). Suppression of tumor cell growth by anthocyanins in vitro. Cancer Inv., 13, 590-594.

Kakinuma, K., Koike, J., Ishibashi, K., Takahashi, W. and Takei, H. (1986). Structure and activity relationship and design of an antimutagen against the UV-Induced mutation of Escherichia coli. Agric. Biol. Chem., 50, 625-631.

Klaunig, J.E. and Rouch, R.J. (1990). Biology of disease: role of inhibition of intercellular communication in carcinogenesis. Lab. Invest., 62, 135-146.

Kurata, R., Adachi, M., Yamakawa, O. and Yoshimoto, K. (2007). Growth suppression of human cancer cells by polyphenolics from sweet potatoes (Ipomea batatas L.) leaves. J. Agric. Food Chem., 55, 181-190.

Kuroda, Y. and Hara, Y. (1999). Antimutagenic and anticarcinogenic activity of tea polyphenols. Mut. Res., 436, 69-97.

Lewenstein, W.R. (1979). Junctional intercellular communication and the control of growth. Biochim. Biophys. Acta, 560, 1-65.

Maron, D.M. and Ames, B.N. (1983). Revised methods for the salmonella mutagenicity test. Mut. Res., 113, 173-275.

Matesic, D.F., Rupp, H.L., Bonney, W.J., Ruch, R.J. and Trosko, J.E. (1994). Change in gap junction permeability phosphorylation, and number mediated by phorbol ester and non-phorbolester tumor promoters in rat liver epithelial cells. Mol. Carcinogen., 10, 226-236.

Miller, J.H. (1972). Experiments in molecular genetics. Cold Spring Harbor Laboratory Press, New York, pp. 352-355.

Minkova, M., Drenska, D., Pantev, T. and Ovcharov, R. (1990). Antiradiation properties of alpha tocopherol, anthocyanins, and pyracetam administered combined as pretreatment course. Acta Phsiol. Pharmacol. Bulg., 16, 31-36.

Oda, Y., Nakamura, S., Oki, I., Kato, T. and Shinagawa, H. (1985). Evaluation of the new system (umu test) for the detection of environmental mutagens and carcinogens. Mut. Res., 147, 219229.

Oda, Y., Yamazaki, H., Watanabe, M., Nohmi, T. and Shimada, T. (1993). Highly sensitive umu test system for the detection of mutagenic nitroarenes in Sallomonella typhimurium NM309 having high $O$-acetyltransferase and nitroreductase activities. 
Environ. Mol. Mut., 21, 357-364

Oki, T., Masuda, M., Furuta, S., Nishiba, Y., Terahara, N. and Suda, I. (2002). Involvement of anthocyanins and other polyphenolic compounds in radical-scavenging activity of purple-fleshed sweet potato cultivars. J. Food Sci., 67, 1752-1756.

Rabah, I.O., Hou, D.X., Komine, S.I. and Fujii, M. (2004). Potential chemopreventive properities of extract from baked sweet potato (Ipomea batatas Lam. cv. Koganesengam). J. Agric. Food Chem., 52, 7152-7157.

Robbins, R.J. (2003). Phenolic acid in foods: an overview of analytical methodology. J. Agric. Food Chem., 51, 2868-2887.

Rosenkranz, H.S., Pollack, N. and Cunningham, A.R. (2000). Exploring the relationship between the inhibition of gap junctional intercellular communication and other biological phenomena. Carcinog., 21, 1007-1011.

Shinohara, K., Kuroki, S., Miwa, M., Kong, Z.L. and Hosoda, H. (1988). Antimutagenecity of vegetables and fruits. Agric. Biol. Chem., 52, 1369-1375.

Sikdar, M. and Dutta, U. (2008). Traditional phytotherapy among the Nath peoples of Assam. Ethno-med., 2, 39-45.

Suda, I., Oki, T., Masada, M., Kobayashi, M., Nishiba, Y. and
Furuta, S. (2003). Physiological functionality of purple-fleshed sweet potatoes containing anthocyanins and their utilization in foods. Japan Agric. Res. Quart, 37, 167-173.

Thompson, D.P. (1981). Chlorogenic acid and other phenolic compound in fourteen sweet potato cultivars. J. Food Sci., 46, 738740.

Troung, V.D., McFesters, R.F., Thompson, R.J., Dean, L.L. and Shofran, B. (2007). Phenolic acid content and composition in leaves and roots of commercial sweet potato (Ipomea batatas L.) cultivar in United State. J. Food Sci., 72, C343-349.

Yoshimoto, M., Okuno, S., Yamaguchi, M. and Yamakawa, O. (2001). Antimutagenicity of antocyanins in purple-fleshed sweet potato. Bios. Biotech. Biochem., 65, 1652-1655.

Yoshimoto, M., Okuno, S., Yoshinaga, M, Yamakawa, O., Yamaguchi, M. and Yamada, J. (1999). Antimutagenecity of sweet potato (Ipomea batatas) root. Bios. Biotech. Biochem., 13, 537-541.

Yoshimoto, M., Yahara, S., Okuno, S., Shadiul, M.M.S., Ishiquro, K. and Yamakawa, O. (2002). Antimutagenecity of mono-, diand tricaffeoylquinic acid derivatives isolated from sweet potato (Ipomea batatas L.) leaf. Bios. Biotech. Biochem., 66, 23362341. 